\title{
A pot-pourri of new species of Trypetheliaceae resulting from molecular phylogenetic studies
}

\author{
Robert LÜCKING, Matthew P. NELSEN, André APTROOT, \\ Michel N. BENATTI, Nguyen Quoc BINH, Cécile GUEIDAN, \\ Martha Cecilia GUTIÉRREZ, Patricia JUNGBLUTH, H. Thorsten LUMBSCH, \\ Marcelo P. MARCELLI, Bibiana MONCADA, Khwanruan NAKSUWANKUL, \\ Thelma OROZCO, Noris SALAZAR-ALLEN and Dalip K. UPRETI
}

\begin{abstract}
Based on separately obtained and analyzed molecular data and within the framework of a global revision of the family Trypetheliaceae, 21 new species are described, from the Neotropics and tropical Asia, in the genera Architrypethelium (1), Astrothelium (15), Bathelium (1), Nigrovothelium (1), Trypethelium (1), and Viridothelium (2), namely: Architrypethelium lauropaluanum Lücking, M. P. Nelsen \& Marcelli sp. nov., differing from $A$. hyalinum in the perithecia immersed between coarse thallus verrucae and in the additional ascospore septa; Astrothelium aurantiacocinereum Lücking, Naksuwankul \& Lumbsch sp. nov., differing from $A$. aeneum in the prominent, well-delimited, trypethelioid pseudostromata and the absence of pigment on the thallus surface, as well as in the barely lichenized thallus; $A$. carassense Lücking, M. P. Nelsen \& Marcelli sp. nov., differing from $A$. purpurascens in orange, $\mathrm{K}+$ red pseudostroma pigment and the slightly larger ascospores; A. cryptolucens Lücking, M. P. Nelsen \& N. Salazar sp. nov., differing from $A$. carrascoense in the inspersed hymenium; $A$. fijiense Lücking, Naksuwankul \& Lumbsch sp. nov., differing from $A$. cinereorosellum in the presence of lichexanthone on the well-delimited pseudostromata and in the slightly shorter ascospores; $A$. laevithallinum Lücking, M. P. Nelsen \& Marcelli sp. nov., differing from $A$. endochryseum in the smooth thallus; $A$. leucosessile Lücking, M. P. Nelsen \& Aptroot sp. nov., differing from $A$. phlyctaena in the conspicuous, sessile pseudostromata; $A$. macrostomoides Lücking, M. P. Nelsen \& Benatti sp. nov., differing from $A$. macrostomum in the larger ascospores; A. megacrypticum Lücking, M. P. Nelsen \& N. Salazar sp. nov., differing from $A$. longisporum in the single-spored asci and larger ascospores; $A$. nicaraguense Lücking, M. P. Nelsen \& T. Orozco sp. nov.,
\end{abstract}

R. Lücking: Botanic Garden and Botanical Museum Berlin, Königin-Luise-Straße 6-8，D-14195 Berlin, Germany. Email: r.luecking@bgbm.org.

R. Lücking, M. P. Nelsen and H. T. Lumbsch: Integrative Research Center, The Field Museum, 1400 South Lake Shore, Chicago, IL 60605, USA.

A. Aptroot: ABL Herbarium, G.v.d.Veenstraat 107, NL-3762 XK Soest, The Netherlands.

M. N. Benatti and M. P. Marcelli: Instituto de Botânica, Núcleo de Pesquisa em Micologia, Caixa Postal 68041, 04045-972, São Paulo, Brazil.

N. Q. Binh: Vietnam Academy of Science and Technology, Vietnam National Museum of Nature, Department of Biology, 18 Hoang Quoc Viet Street, Cau Giay, Hanoi, Vietnam.

C. Gueidan: Department of Life Sciences, Natural History Museum, Cromwell Road, London, SW7 5BD, UK; and Australian National Herbarium, CSIRO, National Facilities and Collections, National Research Collections Australia, GPO Box 1600, Canberra, ACT 2601, Australia.

M. C. Gutiérrez: Ingeniería Ambiental, Universidad Distrital Francisco José de Caldas, Carrera 5 Este No. 15-82, Av. Circunvalar, Bogotá, Colombia.
P. Jungbluth: Departamento Zooctenia e Ciências Biológicas, Universidade Federal de Santa Maria. Av. Idependência, 3751, Bairro Vista Alegre, CEP 98300-000, Palmeira das Missões, Rio Grande do Sul, Brazil.

B. Moncada: Licenciatura en Biología, Universidad Distrital Francisco José de Caldas, Cra. 4 No. 26D-54, Torre de Laboratorios, Herbario, Bogotá, Colombia; and Research Associate, Science and Education, The Field Museum, 1400 South Lake Shore, Chicago, IL 60605, USA.

K. Naksuwankul: Department of Biology and Natural Medicinal Mushroom Museum, Faculty of Science, Mahasarakham University, Kantarawichai, Maha Sarakham Province, 44150 Thailand.

N. Salazar-Allen: Smithsonian Tropical Research Institute, Box 0843-03092, Balboa, Ancon, Panama.

T. Orozco: Herbario Nacional de Nicaragua, Universidad Centroamericana, Apartado 69, Managua, Nicaragua.

D. K. Upreti: National Botanical Research Institute (CSIR), Rana Pratap Marg, Lucknow, 226001 Uttar Pradesh, India. 
differing from $A$. gigantosporum in the smaller ascospores; $A$. norisianum Lücking, M. P. Nelsen \& Aptroot sp. nov., differing from $A$. sepultum in the distinct, well-delimited pseudostromata; A. obtectum Lücking, M. P. Nelsen \& Benatti sp. nov., differing from $A$. nigrocacuminum in the smaller ascospores; $A$. sordithecium Lücking, M. P. Nelsen \& Marcelli sp. nov., differing from $A$. leucothelium in the inspersed hymenium and the absence of lichexanthone from the thallus surface outside the pseudostromata; $A$. subendochryseum Lücking, M. P. Nelsen \& Marcelli sp. nov., differing from $A$. endochryseum in the absence of pigment in the pseudostromata and the lateral thallus cover of the pseudostromata; $A$. subinterjectum Lücking, M. P. Nelsen \& Jungbluth sp. nov., differing from A. obtectum in the smaller pseudostromata and smaller ascospores, and from $A$. interjectum in the diffuse pseudostromata and smaller ascospores; Bathelium porinosporum Lücking, M. P. Nelsen \& Gueidan sp. nov., differing from other Bathelium species in the 3-septate, euseptate ascospores; Nigrovothelium bullatum Lücking, Upreti \& Lumbsch sp. nov., differing from $N$. tropicum in the bullate thallus; Trypethelium tolimense Lücking, Moncada \& M. Gut. sp. nov., differing from T. xanthoplatystomum in the absence of a yellow-orange pigment on the pseudostromata and the $\mathrm{K}+$ yellow (not $\mathrm{K}+$ red) medullary pigment; Viridothelium tricolor Lücking, M. P. Nelsen \& N. Salazar sp. nov., characterized by black perithecia with a lateral ostiole immersed in white pseudostromata strongly contrasting with the surrounding brown thallus, in combination with 2-spored asci and large, muriform ascospores; and $V$. vonkonratii Lücking, Naksuwankul \& Lumbsch sp. nov., differing from $V$. virens in larger ascospores and mostly solitary ascomata. All species are illustrated and their taxonomy and phylogenetic relationships are discussed. ITS barcoding sequences are reported for five specimens of Bathelium porinosporum.

Key words: Brazil, Colombia, Fiji, lichen, New Caledonia, Panama, taxonomy, Vietnam

Accepted for publication 6 fune 2016

\section{Introduction}

Next to Graphidaceae, the lichenized fungal family Trypetheliaceae is the most important and conspicuous element of crustose lichen communities in tropical forest and savanna ecosystems (Komposch \& Hafellner 1999, 2000, 2002, 2003; Komposch et al. 2002; Aptroot et al. 2008, 2013; Aptroot 2009a, b). The number of species recognized in this family has greatly increased recently, not only due to the discovery of new species (Aptroot et al. 2013; Lima et al. 2013; Weerakoon \& Aptroot 2014; CórdovaChávez et al. 2014; Aptroot \& Cáceres 2016; Flakus et al. 2016), but also based on phylogenetic studies which resulted in a refined species concept (Aptroot \& Lücking 2016; Lücking et al. 2016). Previously unrecognized species are often discovered because the placement of specimens identified with currently used names on a phylogenetic tree results in conflicting topologies, which then triggers a more detailed study of the sequenced material and the discovery of subtle morphological features characterizing separate clades.
In this paper we describe a large number of new taxa, including material which, prior to phylogenetic studies, had been identified as common existing species. In these cases, it turned out that the sequenced material was not conspecific with the taxon on which the name was based, and in many cases not even closely related. Hence, these species are here formally described, illustrated, and discussed in a phylogenetic and morphological context. Most belong in the redefined, megadiverse genus Astrothelium, which includes species previously classified in Campylothelium, Cryptothelium, Laurera, and Trypethelium (Nelsen et al. 2014; Aptroot \& Lücking 2016; Lücking et al. 2016).

\section{Material and Methods}

Thallus morphology was examined using a LEICA MS5 dissecting microscope. Sections of thalli and ascomata were cut by hand with a razor blade and examined in squash preparations mounted in water, $\mathrm{KOH}$ and Lugol's solution, using a ZEISS Axioskop 2 compound microscope. All measurements are given in water. TLC was carried out using standard techniques with solvent C, following Orange et al. (2010). Molecular sequence data of the mitochondrial small subunit (mtSSU) and 
the nuclear large subunit (nuLSU) of the rDNA cistron were obtained for most specimens following previously published protocols (Nelsen et al. 2009, 2011, 2014) and are published separately (Nelsen et al. 2009, 2011, 2014; Lücking et al. 2016).

\section{Results and Discussion}

\section{Architrypethelium lauropaluanum Lücking, M. P. Nelsen \& Marcelli sp. nov.}

\author{
MycoBank No.: MB 817268
}

Differing from Architrypethelium hyalinum in the perithecia immersed between coarse thallus verrucae and in the additional ascospore septa.

Type: Brazil, Minas Gerais, Serra do Caraça, Reserva Particular do Patrimônio Natural (RPPN) Santuário do Caraça, Belchior trail, $20^{\circ} 06^{\prime} \mathrm{S}, 4^{\circ} 29^{\prime} \mathrm{W}, 1300-1400 \mathrm{~m}$, Atlantic rainforest, disturbed gallery forest remnants (mata de galeria or floresta ombrófila densa montana) along small river leading to Cascatinha Waterfall, 27 July 2010, R. Lücking 31021 (SP-holotype; B, F-isotypes).

(Fig. 1A)

Thallus crustose, corticolous, continuous, $\leq 7 \mathrm{~cm}$ diam., coarsely bumpy with bumps 1-3 mm diam. (gall-forming), olive-yellow; in section with thin cortex and with irregular photobiont layer and thick medulla immersed in the modified periderm; photobiont layer and medulla encrusted with numerous, small crystals.

Perithecia solitary, deeply immersed between the thallus galls, with apical to more or less eccentric ostioles; ostioles papilliform, $0.1-0.2 \mathrm{~mm}$ diam., brownish; perithecia subglobose to pyriform, with ostiolar channels oriented irregularly, $0.5-0.7 \mathrm{~mm}$ wide and $\leq 1 \mathrm{~mm}$ high. Excipulum in section $50-150 \mu \mathrm{m}$ thick, carbonized, covered with amorphous, orange-brown tissue. Hamathecium composed of densely anastomosing, $0.5 \mu \mathrm{m}$ thick, net-like paraphyses embedded in a gelatinous matrix, clear, IKI-; ostiolar channel clear. Ascospores 8 per ascus, fusiform, 3-7-septate (the last septa often indistinct or not well developed), with distosepta and angular lumina but not distinctly diamond-shaped, 100-120 × 25-30 $\mu \mathrm{m}$, hyaline, IKI-.

Secondary chemistry. Thallus (not perithecia) with lichexanthone, UV+ yellow.
Etymology. This new species is dedicated to Padre Lauro Palú, long-term director of the Santuário do Caraça and colleague of Marcelo Marcelli.

Notes. This new species is placed here in the genus Architrypethelium due to the very large ascospores that are principally 3-septate, with a septal structure of the Architrypethelium type (Aptroot 1991; Nelsen et al. 2014; Aptroot \& Lücking 2016). However, the ascospores develop 2-4 additional septa that are less distinct than the three primary septa. Within Architrypethelium, only $A$. hyalinum Aptroot has ascospores that remain hyaline, and that species also produces lichexanthone on the thallus, but its morphology is different, with the perithecia superficial and not immersed between strongly prominent thallus verrucae. Several species of Astrothelium produce similar ascospores, such as $A$. megalophthalmum (Müll. Arg.) Aptroot \& Lücking with pseudostromata and lacking lichexanthone, and A. pictum Aptroot with pseudostromata and a red medullary pigment. Astrothelium diplocarpoides Müll. Arg. has smaller, typically astrothelioid ascospores, an inspersed hamathecium, and produces lichexanthone on the thallus and the perithecial warts.

Additional specimens examined. Peru: Madre de Dios: Los Amigos Research and Training Center, Centro de Investigación y Capacitación Río Los Amigos (CICRA), $90 \mathrm{~km} \mathrm{~W}$ of Puerto Maldonado; $12^{\circ} 35^{\prime} \mathrm{S}, 70^{\circ} 06^{\prime} \mathrm{W}$, $270 \mathrm{~m}$, tropical lowland rainforest, on bark of tree, viii 2008, M. P. Nelsen s. n. (F).

\section{Astrothelium aurantiacocinereum Lücking, Naksuwankul \& Lumbsch sp. nov.}

MycoBank No.: MB 817269

Differing from Astrothelium aeneum in the prominent, well-delimited, trypethelioid pseudostromata and the absence of pigment on the thallus surface, as well as in the barely lichenized thallus.

Type: New Caledonia, Province Sud, Dumbéa, Monts Dzumac, along roadside up to the mountain top, $22^{\circ} 02^{\prime} \mathrm{S}, 166^{\circ} 28^{\prime} \mathrm{E}, 920 \mathrm{~m}$, relict montane forest, on bark, September 2012, K. B. Naksuwankul \& H. T. Lumbsch 7537 (IRD-holotype; B, F-isotypes).

(Fig. 1B \& C) 

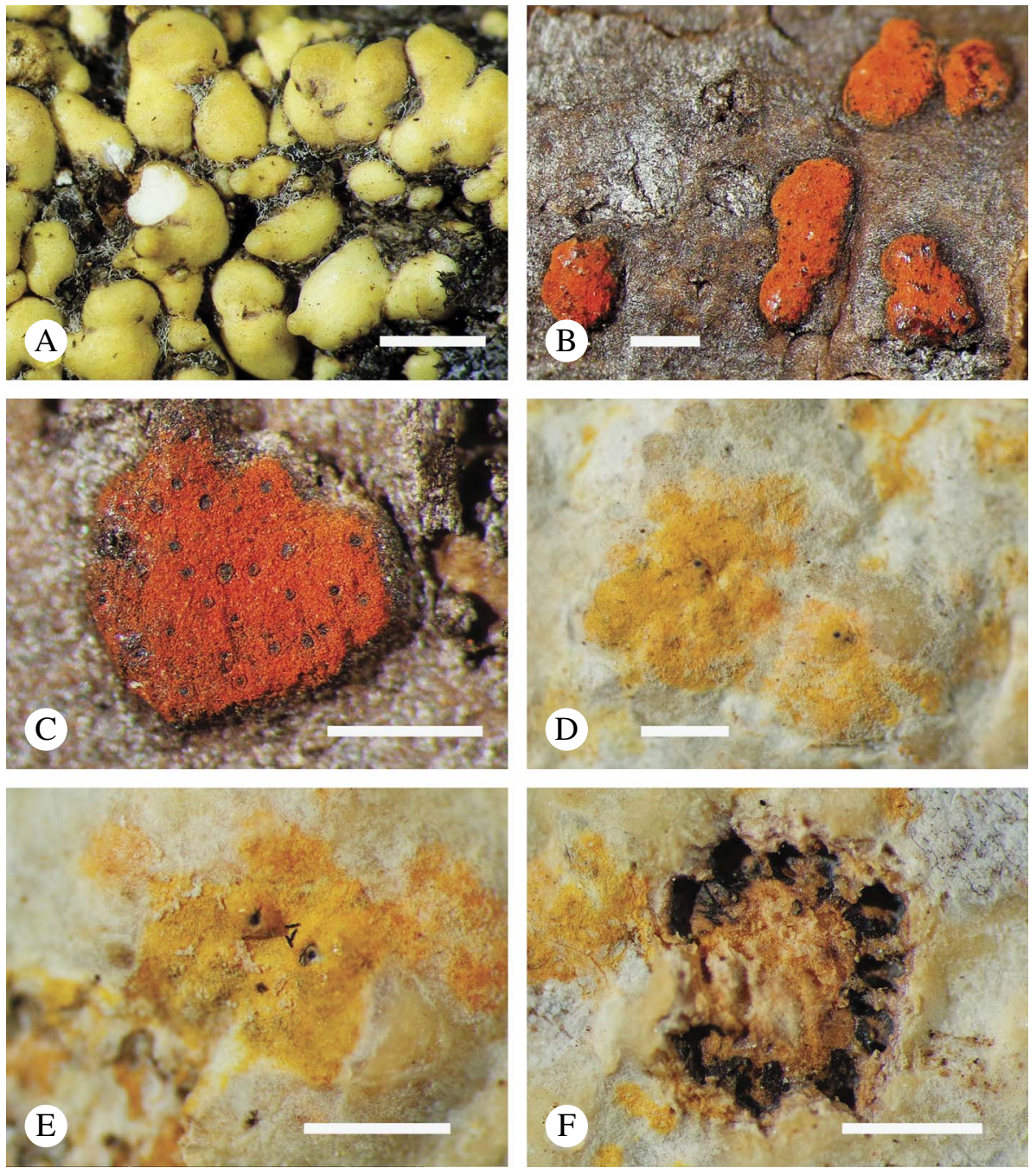

FIG. 1. A, Architrypethelium lauropaluanum (isotype), bullate thallus with immersed, hidden ascomata. B \& C, Astrothelium aurantiacocinereum (isotype), thallus with pseudostromatic ascomata. D-F, A. carassense (isotype); $\mathrm{D} \& \mathrm{E}$, thallus with immersed ascomata; $\mathrm{F}$, fused ascomata exposed. Scales: $\mathrm{A}-\mathrm{F}=1 \mathrm{~mm}$. In colour online.

Thallus crustose, corticolous, continuous, $\leq 10 \mathrm{~cm}$ diam., smooth to uneven, dark grey to brownish grey; in section thinly corticate and with indistinct, endoperidermal photobiont layer (appearing barely lichenized).

Perithecia 5-20 aggregated in rounded to irregular or sometimes elongate pseudostromata, with separate, apical ostioles; pseudostromata 1-3 mm long and 1-2 mm wide, prominent to sessile, $\leq 0.6 \mathrm{~mm}$ high, covered by a thick, carbonized layer with a deep orange pigment layer above, $\mathrm{K}+$ purple; ostioles visible as blackish dots, $0.03-0.05 \mathrm{~mm}$ diam.; invididual perithecia subglobose, $0.3-0.4 \mathrm{~mm}$ wide and $0.3-0.4 \mathrm{~mm}$ high, space between perithecia filled with amorphous, orange-brown tissue. Excipulum in section $30-50 \mu \mathrm{m}$ thick, carbonized. Hamathecium composed of densely anastomosing, $0.5 \mu \mathrm{m}$ thick, net-like paraphyses embedded in a gelatinous matrix, clear, IKI-; ostiolar channel clear. Ascospores 8 per ascus, 
fusiform-ellipsoid, 3-septate with distosepta and diamond-shaped lumina, 22-27 $\times$ 8-10 $\mu \mathrm{m}$, hyaline, IKI-.

Secondary chemistry. Pseudostromata covered with deep orange pigment that bleeds purple; base of thallus bleeding yellow (reaction of substratal periderm?).

Etymology. The epithet refers to the strong contrast between the orange pseudostromata and the grey thallus.

Notes. This is a unique new species that at first glance resembles a true Trypethelium (Nelsen et al. 2014; Aptroot \& Lücking 2016) but produces astrothelioid ascospores. Only a small number of species in Astrothelium, including $A$. aeneum (Eschw.) Aptroot \& Lücking, $A$. inspersaeneum E. L. Lima et al., and $A$. neogalbineum (R. C. Harris) Aptroot \& Lücking, have orange pseudostromata combined with 3-septate ascospores. However, in all these three species the perithecia are immersed to erumpent and dispersed to aggregate but do not form prominent to sessile, trypethelioid pseudostromata. Another unique feature is the barely lichenized, dark grey thallus that strongly contrasts with the orange pseudostromata. Barely lichenized thalli are thus far known only from basal lineages within the family but not in the derived genus Astrothelium. Unfortunately, no sequence data could be obtained for this material but it is possible that it represents an unrecognized genus.

\section{Astrothelium carassense Lücking, M. P. Nelsen \& Marcelli sp. nov.}

\section{MycoBank No.: MB 817270}

Differing from Astrothelium purpurascens in the orange, $\mathrm{K}+$ red pseudostroma pigment and the slightly larger ascospores.

Type: Brazil, Minas Gerais, Serra do Caraça, Reserva Particular do Patrimônio Natural (RPPN) Santuário do Caraça, Belchior trail, $20^{\circ} 06^{\prime} \mathrm{S}, 43^{\circ} 29^{\prime} \mathrm{W}, 1300-1400 \mathrm{~m}$, Atlantic rainforest, disturbed gallery forest remnants (mata de galeria or floresta ombrófila densa montana) along small river leading to Cascatinha Waterfall, 27 July 2010, R. Lücking 31004 (SP-holotype; B, F-isotypes).

\section{(Fig. 1D-F)}

Thallus crustose, corticolous, continuous, $\leq 10 \mathrm{~cm}$ diam., uneven to bumpy with bumps 1-2 mm diam. (gall-forming), very pale olive-yellow, irregularly white-pruinose (appearing roughened); in section corticate, with photobiont layer deeply immersed in the modified periderm.

Perithecia 8-11 aggregated in concentric circles with fused, centrally shared ostiole, completely immersed in pseudostromata; pseudostromata 2-4 mm diam., slightly elevated over thallus level, uneven to bumpy, covered with orange pigment that penetrates into the cortex and periderm, central ostiole papilliform, 0.3-0.4 mm diam., with black dot; individual perithecia pyriform, arranged laterally with ostiolar channel oriented towards the centre, $0.5-0.6 \mathrm{~mm}$ wide and $\leq 1 \mathrm{~mm}$ long ('high'). Excipulum in section $20-30 \mu \mathrm{m}$ thick, carbonized; space between individual perithecia filled with amorphous, orangebrown tissue. Hamathecium composed of densely anastomosing, $0.5 \mu \mathrm{m}$ thick, net-like paraphyses embedded in a gelatinous matrix, clear, IKI-; ostiolar channel strongly inspersed with grey-brown oil droplets. Ascospores 8 per ascus, oblong-fusiform, densely muriform, with 15-19 transverse distosepta and approximately the same number of secondary eusepta and 3-7 longitudinal eusepta per segment, $100-170 \times 30-40 \mu \mathrm{m}$, hyaline, IKI-, without strong median thickening.

Secondary chemistry. Orange anthraquinone covering the pseudostromata, $\mathrm{K}+$ red.

\section{Etymology. Named after the type locality.}

Notes. This new species is characterized by the astrothelioid perithecia with fused ostioles, the orange anthraquinone covering the pseudostromata, and the large, muriform ascospores. Only four other species of Astrothelium are known with this type of perithecial arrangement, muriform ascospores, and presence of pigments (Aptroot \& Lücking 2016). Astrothelium isabellinum Eschw. and $A$. purpurascens (Müll. Arg.) 
Aptroot \& Lücking have a red pseudostroma pigment reacting $\mathrm{K}+$ green; in addition, A. isabellinum has 2-spored asci and A. purpurascens has slightly smaller ascospores. Astrothelium praetervisum (Müll. Arg.) Aptroot \& Lücking features an orange thallus pigment but has small ascospores not exceeding $70 \times 25 \mu \mathrm{m}$. Most similar is Astrothelium amazonum (R. C. Harris) Aptroot \& Lücking, which shares the orange pseudostroma pigment but differs in the smaller ascospores not exceeding $100 \times 30 \mu \mathrm{m}$.

\section{Astrothelium cryptolucens Lücking, M. P. Nelsen \& N. Salazar sp. nov.}

\author{
MycoBank No.: MB 817271
}

Differing from Astrothelium carrascoense in the inspersed hymenium.

Type: Panama, Panamá, Altos de Campana National Park, $50 \mathrm{~km} \mathrm{~W}$ of Panama City near the town of Capira, access gravel road leading to forest, $8^{\circ} 42^{\prime} \mathrm{N}, 79^{\circ} 57^{\prime} \mathrm{W}$, 500-600 m, submontane rainforest, on bark of exposed roadside trees, 14 March 2009, R. Lücking 27019 (PMA-holotype; B, F-isotypes).

(Fig. 2A-D)

Thallus crustose, corticolous, continuous, $\leq 10 \mathrm{~cm}$ diam., uneven to coarsely bumpy with bumps $1-3 \mathrm{~mm}$ diam. or often elongate (gall-forming), olive-yellow; in section with thin cortex and with irregular photobiont layer and thick medulla immersed in the modified periderm; photobiont layer and medulla encrusted with numerous, small crystals.

Perithecia loosely aggregated and completely immersed in irregular to linear pseudostromata, with lateral, separate ostioles; pseudostromata 2-5 mm long and 1-3 mm wide, immersed, always developed between galls, often anastomosing, uneven and cracked into numeros small 'areoles', covered with a brownish white layer; ostioles papilliform, $0.05-0.10 \mathrm{~mm}$ diam., brownish; perithecia pyriform, arranged laterally with ostiolar channels oriented irregularly, $0.3-0.5 \mathrm{~mm}$ wide and $\leq 1 \mathrm{~mm}$ long ('high'). Excipulum in section 50-150 $\mu \mathrm{m}$ thick, carbonized; space between individual perithecia filled with amorphous, orange-brown tissue. Hamathecium composed of densely anastomosing, $0.5 \mu \mathrm{m}$ thick, netlike paraphyses embedded in a gelatinous matrix, clear, IKI-; upper part of hamathecium and ostiolar channel strongly inspersed. Ascospores 1-2 per ascus, oblong-ellipsoid, densely muriform with distinct median constriction and distinctly thickened median septum and thick outer wall, 150-200x 50-60 $\mu \mathrm{m}$, hyaline, IKI-.

Secondary chemistry. Pseudostromata with lichexanthone, UV+ yellow.

Etymology. The epithet refers to the cryptothelioid habit with completely immersed perithecia and the presence of lichexanthone.

Notes. This new species belongs in the Astrothelium sepultum complex, with large, muriform, centrally constricted ascospores and lichexanthone. It differs from other species in this complex in the distinctly gallforming thallus with numerous galls strongly contrasting with the pseudostromatic, UV+ yellow areas. Astrothelium cryptolucens appears to be the only species in this complex in which the perithecia maintain separate ostioles, in spite of their dense arrangement in pseudostromata. This species is close to A. carrascoense Flakus et al. (Flakus et al. 2016), which differs by the inspersed hamathecium.

\section{Astrothelium fijiense Lücking, Naksuwankul \& Lumbsch sp. nov.}

\section{MycoBank No.: MB 817272}

Differing from Astrothelium cinereorosellum in the presence of lichexanthone on the well-delimited pseudostromata and in the slightly shorter ascospores.

Type: Fiji, Viti Levu Island, Suva area, Nakoba Levu, Telecommunication Tower, $18^{\circ} 04^{\prime} \mathrm{S}, 178^{\circ} 25^{\prime} \mathrm{E}, 750 \mathrm{~m}$, secondary forest on steep slope, on bark, 2011, H. T. Lumbsch E K. B. Naksuwankul 20500k (SUVAholotype; B, F, MSUT-isotypes).

\section{(Fig. 2E \& F)}

Thallus crustose, corticolous, continuous, $\leq 5 \mathrm{~cm}$ diam., smooth to uneven, light oliveyellow; in section with thick, cartilaginous 

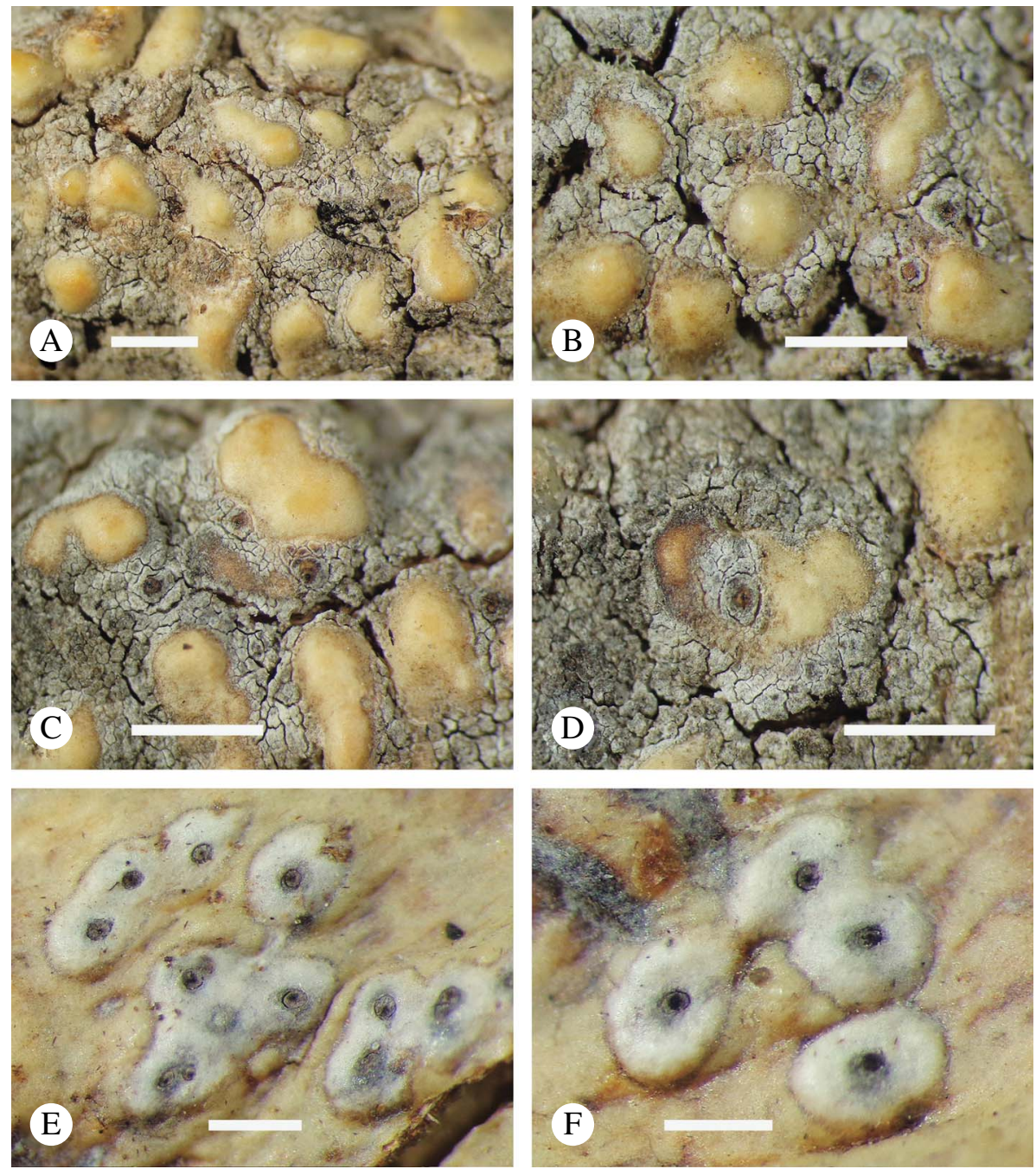

FIG. 2. A-D, Astrothelium cryptolucens (isotype), bullate thallus with immersed, largely hidden ascomata only visible by their ostioles. E \& F, A. fijiense (isotype), thallus with erumpent ascomata covered by whitish layer. Scales: $\mathrm{A}-\mathrm{F}=1 \mathrm{~mm}$. In colour online.

cortex, thin and irregular, epiperidermal photobiont layer, and distinct, mostly epiperidermal medulla, encrusted with small, grey crystals.

Perithecia solitary or 2-4 aggregated in rounded, often fused and then elongate pseudostromata, with separate, apical ostioles; pseudostromata $0.7-1.5 \mathrm{~mm}$ diam. and $\leq 3 \mathrm{~mm}$ long when fused, erumpent, applanate, $0.4-0.5 \mathrm{~mm}$ thick, covered by a whitish layer contrasting with the surrounding thallus; ostioles appearing as blackish spots, $0 \cdot 1-0.2 \mathrm{~mm}$ diam.; individual perithecia applanately subglobose, $0.4-0.6 \mathrm{~mm}$ wide and $\leq 0.4 \mathrm{~mm}$ high. Excipulum in section $30-60 \mu \mathrm{m}$ thick, carbonized, covered by amorphous, orangebrown tissue. Hamathecium composed of densely anastomosing, $0.5 \mu \mathrm{m}$ thick, net-like paraphyses embedded in a gelatinous matrix, densely inspersed with sordid yellowish grey 
oil droplets, IKI-; ostiolar channel inspersed. Ascospores 8 per ascus, narrowly fusiform, 7-septate with distosepta and diamond-shaped lumina, $40-50 \times 11-13 \mu \mathrm{m}$, hyaline, IKI-.

Secondary chemistry. Lichexanthone on the thallus and pseudostromata, UV+ yellow.

Etymology. Named after the type locality.

Notes. Astrothelium fijiense is characterized by the usually rounded, erumpent, applanate pseudostromata contrasting with the thallus, the inspersed hamathecium, 7-septate ascospores, and the presence of lichexanthone. The most similar taxon is $A$. cinereorosellum (Kremp.) Aptroot \& Lücking, which differs in the absence of lichexanthone on the pseudostromata and in the slightly longer ascospores, and the lack of distinct, contrasting pseudostromata.

\section{Astrothelium laevithallinum Lücking, M. P. Nelsen \& Marcelli sp. nov.}

MycoBank No.: 817273

Differing from Astrothelium endochryseum in the smooth thallus.

Type: Brazil, Minas Gerais, Serra do Caraça, Reserva Particular do Patrimônio Natural (RPPN) Santuário do Caraça, Cascatinha Waterfall, $20^{\circ} 06^{\prime} \mathrm{S}, 43^{\circ} 29^{\prime} \mathrm{W}$, $1300-1400 \mathrm{~m}$, Atlantic rainforest, disturbed gallery forest remnants (mata de galeria or floresta ombrófila densa montana) near waterfall, 27 July 2010, R. Lücking 31061 (SP-holotype; F-isotype).

\section{(Fig. 3A \& B)}

Thallus crustose, corticolous, continuous, $\leq 5 \mathrm{~cm}$ diam., smooth to uneven, green; in section with thick, cartilaginous cortex and distinct, epiperidermal photobiont layer, and thick medulla immersed in the periderm.

Perithecia 3-7 aggregated in irregular pseudostromata, with separate, apical ostioles; pseudostromata 1-3 mm diam., prominent, $\leq 1 \mathrm{~mm}$ high, covered by a greybrown thallus layer; internally between the perithecia filled with yellow, $\mathrm{K}+$ red pigment granules, in section bleeding deep yellow then deep orange to cinnabar red, covered by a carbonized layer with a thin cortex above; ostioles visible as black dots, $0.05-0.10 \mathrm{~mm}$ diam.; individual perithecia subglobose, 0.8 $1.0 \mathrm{~mm}$ wide and $0.7-0.9 \mathrm{~mm}$ high. Excipulum in section $20-30 \mu \mathrm{m}$ thick, carbonized, laterally covered by dense pigment granules. Hamathecium composed of densely anastomosing, $0.5 \mu \mathrm{m}$ thick, net-like paraphyses embedded in a gelatinous matrix, clear, IKI-; ostiolar channel clear. Ascospores 8 per ascus, fusiform, 3-septate with distosepta and diamond-shaped lumina, 35-42 × 10-12 $\mu \mathrm{m}$, hyaline, IKI-.

Secondary chemistry. Pseudostromata with yellow pigment that bleeds first deep yellow, then deep orange to cinnabar red.

Etymology. The name refers to the smooth thallus as compared to its closest relative with a bullate thallus (see below).

Notes. This new species is related and similar to Astrothelium endochryseum (Vain.) Aptroot \& Lücking, but differs mainly in the smooth, not bullate thallus. Both species are phylogenetically distinct, emphasizing the importance of thallus morphology as a taxonomic character (Lücking et al. 2016).

\section{Astrothelium leucosessile Lücking, $\mathbf{M}$. P. Nelsen \& Aptroot sp. nov.}

MycoBank No.: MB 817274

Differing from Astrothelium phlyctaena in the conspicuous, sessile pseudostromata.

Type: Panama, Panamá, Altos de Campana National Park, $50 \mathrm{~km} \mathrm{~W}$ of Panama City near the town of Capira, access gravel road leading to forest, $8^{\circ} 42^{\prime} \mathrm{N}, 79^{\circ} 57^{\prime} \mathrm{W}$, 500-600 m, submontane rainforest, on bark of exposed roadside trees, 14 March 2009, R. Lücking 27093 (PMA-holotype; B, F-isotypes).

(Fig. 3C \& D)

Thallus crustose, corticolous, continuous, $\leq 5 \mathrm{~cm}$ diam., smooth to uneven, light olivegrey with streaks of yellowish white pruina; in section thinly corticate, with photobiont layer immersed in the uppermost periderm layer. 

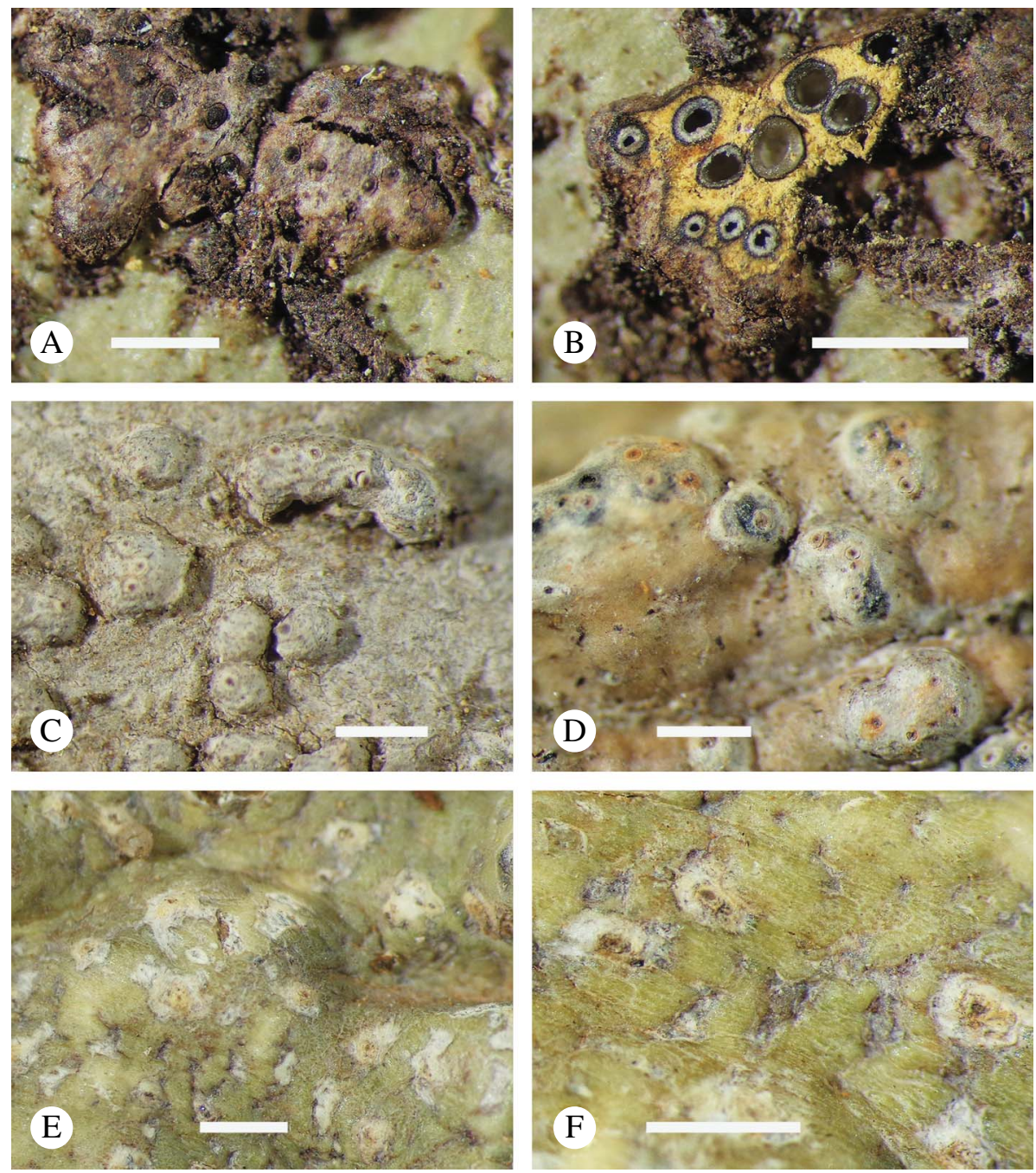

FIG. 3. A \& B, Astrothelium laevithallinum (isotype); A, thallus with pseudostromatic ascomata; B pseudostromatic ascomata with yellow medullary pigment. C \& D, A. leucosessile (isotype), thallus with prominent to sessile, pseudostromatic ascomata. E \& F, A. macrostomoides (isotype), thallus with immersed ascomata. Scales: $\mathrm{A}-\mathrm{F}=1 \mathrm{~mm}$. In colour online.

Perithecia 2-5 aggregated in irregular to elongate pseudostromata with separate, apical ostioles; pseudostromata 1-2 mm long and $0.6-1.5 \mathrm{~mm}$ wide, prominent to sessile, $0.4-0.6 \mathrm{~mm}$ high, covered by a whitish thallus layer and often with streaks of yellowish white pruina; ostioles appearing as blackish dots, $0.03-0.05 \mathrm{~mm}$ diam.; individual perithecia subglobose but with a distinctly pyriform chamber with long ostiolar channel, $0.4-0.5 \mathrm{~mm}$ wide and $\leq 0.5 \mathrm{~mm}$ high. Excipulum in section $50-120 \mu \mathrm{m}$ thick, strongly carbonized; narrow space between individual perithecia filled with amorphous, orange-brown tissue. Hamathecium composed of densely anastomosing, $0.5 \mu \mathrm{m}$ thick, net-like paraphyses embedded in a gelatinous matrix, densely inspersed, IKI-; ostiolar channel densely inspersed. Ascospores 8 per ascus, fusiform-ellipsoid, 
3-septate with distosepta and diamond-shaped lumina, $20-25 \times 8-10 \mu \mathrm{m}$, hyaline, IKI-.

Secondary chemistry. Lichexanthone on the thallus and especially the pseudostromata, $\mathrm{UV}+$ yellow.

Etymology. The epithet refers to the whitish, sessile pseudostromata.

Notes. This new species agrees with the broad concept of Astrothelium phlyctaena (Fée) Aptroot \& Lücking (= Trypethelium ochroleucum (Eschw.) Nyl.), but is not closely related to the latter species (Lücking et al. 2016). While in $A$. phlyctaena the perithecia are dispersed to irregularly aggregate and erumpent, in $A$. leucosessile they are clearly organized in prominent to sessile pseudostromata, closely resembling a species of Trypethelium s. str.

Additional specimens examined. Panama: Panamá: Altos de Campana National Park, $50 \mathrm{~km}$ W of Panama City near the town of Capira, access gravel road leading to forest, $8^{\circ} 42^{\prime} \mathrm{N}, 79^{\circ} 57^{\prime} \mathrm{W}, 500-600 \mathrm{~m}$, submontane rainforest, on bark of exposed roadside trees, 2009, R. Lücking 27059 (F).-Peru: Madre de Dios: Los Amigos Research and Training Center, Centro de Investigación y Capacitación Río Los Amigos (CICRA), 90 km W of Puerto Maldonado, $12^{\circ} 35^{\prime} \mathrm{S}, 70^{\circ} 6^{\prime} \mathrm{W}, 270 \mathrm{~m}$, tropical lowland rainforest, on bark of tree, viii 2008, M. P. Nelsen s. n. (F).-Brazil: Rondônia: Porto Velho, Parque Natural Municipal de Porto Velho, 8\%41'10"S, $63^{\circ} 52^{\prime} 05^{\prime \prime W}, 100 \mathrm{~m}$, on tree bark in primary rainforest, 2012, M. Cáceres $\mathcal{E} A$. Aptroot 11201 (B, ISE).

\section{Astrothelium macrostomoides} Lücking, M. P. Nelsen \& Benatti sp. nov.

\section{MycoBank No.: MB 817275}

Differing from Astrothelium macrostomum in the larger ascospores.

Type: Brazil, Minas Gerais, Serra do Caraça, Reserva Particular do Patrimônio Natural (RPPN) Santuário do Caraça, trail through forest to chapel, $20^{\circ} 06^{\prime} \mathrm{S}, 43^{\circ} 29^{\prime} \mathrm{W}$, $1300-1400 \mathrm{~m}$, Atlantic rainforest, relatively wellpreserved gallery forest (mata de galeria or floresta ombrófila densa montana) along small river, 27 July 2010, R. Lücking 31243 (SP-holotype; B, F-isotype).

(Fig. 3E \& F)

Thallus crustose, corticolous, continuous, $\leq 7 \mathrm{~cm}$ diam., uneven to coarsely bullate (gall-forming), olive-green; in section with thick, cartilaginous cortex and distinct, epiperidermal photobiont layer, and indistinct medulla partially immersed in the periderm and encrusted with numerous small, grey crystals.

Perithecia 5-10 aggregated in rounded to irregular, diffuse pseudostromata, with fused, eccentric ostioles forming a common ostiole more or less in the centre of the pseudotromata; pseudostromata $1.5-2.5 \mathrm{~mm}$ diam., erumpent, $\leq 1.5 \mathrm{~mm}$ high, covered by olivegreen thallus except for the whitish, contrasting ostiolar area; ostioles papilliform, $0.2-0.3 \mathrm{~mm}$ diam., yellowish brown; individual perithecia pyriform, $0.4-0.6 \mathrm{~mm}$ wide and $\leq 1 \mathrm{~mm}$ high. Excipulum in section $30-50 \mu \mathrm{m}$ thick, carbonized, space between perithecia filled with amorphous, orange-brown tissue. Hamathecium composed of densely anastomosing, $0.5 \mu \mathrm{m}$ thick, net-like paraphyses embedded in a gelatinous matrix, clear, IKI-; ostiolar channel clear. Ascospores 8 per ascus, fusiform, 5(-7)-septate with distosepta and diamond-shaped lumina, 80-110 $\times$ 17-25 $\mu \mathrm{m}$, hyaline, IKI-.

Secondary chemistry. Pseudostromata with lichexanthone, UV+ yellow.

Etymology. The epithet refers to the similarity with Astrothelium macrostomum.

Notes. Astrothelium macrostomoides is characterized by fused perithecia with lichexanthone on the pseudostromata and by rather large, predominantly 5-septate ascospores. Most similar is A. macrostomum Aptroot, which differs chiefly in the smaller ascospores. Astrothelium diplocarpoides Müll. Arg. has an inspersed hamathecium and both thallus and pseudostromata covered with lichexanthone, and its ascospores are also slightly smaller.

\section{Astrothelium megacrypticum Lücking, M. P. Nelsen \& N. Salazar sp. nov.}

MycoBank No.: MB 817276

Differing from Astrothelium longisporum in the singlespored asci and larger ascospores. 
Type: Panama, Panamá, Altos de Campana National Park, $50 \mathrm{~km} \mathrm{~W}$ of Panama City near the town of Capira, access gravel road leading to forest, $8^{\circ} 42^{\prime} \mathrm{N}$, $79^{\circ} 57^{\prime} \mathrm{W}, 500-600 \mathrm{~m}$, submontane rainforest, on bark of exposed roadside trees, 14 March 2009, R. Lücking 27017 (PMA - holotype; B, F-isotypes).

(Fig. 4A-D)

Thallus crustose, corticolous, continuous, $\leq 10 \mathrm{~cm}$ diam., uneven to bumpy with irregular, dispersed bumps 1-2 $\mathrm{mm}$ diam. (gall-forming), olive-green; in section with thick, cartilaginous cortex, thick, epiperidermal photobiont layer with crenulate upper limit against the cortex, and massive, endoperidermal medulla within the modified periderm, encrusted with numerous small, grey crystals.

Perithecia solitary, deeply immersed in the thallus, not visible except for the accumulation of extruded ascospores near the ostioles, with eccentric to lateral, cryptic ostiole; individual perithecia subglobose, $0.7-1.0 \mathrm{~mm}$ wide and $\leq 1 \mathrm{~mm}$ high. Excipulum in section $30-50 \mu \mathrm{m}$ thick, carbonized, covered by amorphous, orange-brown tissue. Hamathecium composed of densely anastomosing, $0.5 \mu \mathrm{m}$ thick, net-like paraphyses embedded in a gelatinous matrix, strongly inspersed with large oil droplets, IKI-; ostiolar channel strongly inspersed with large oil droplets. Ascospores 1 per ascus, oblong-ellipsoid, densely muriform, 250-350 × 40-60 $\mu \mathrm{m}$, hyaline, IKI-.

Secondary chemistry. No substances detected.

Etymology. The name refers to the cryptic perithecia and the very large ascospores.

Notes. This new species is characterized by the campylothelioid perithecia which are completely immersed and not visible from the outside except for the accumulation of extruded ascospores near the ostiole. The ascospores are among the largest in the family and probably the largest in the genus, being matched only by ascospores in the genus Aptrootia. Most similar are Astrothelium colombiense Aptroot and A. longisporum Aptroot et al. Both share solitary perithecia, hymenial inspersion, and large, muriform ascospores with the new species. However, the ascospores are smaller in both species and occur in numbers of eight in $A$. longisporum. In addition, $A$. columbiense features apical ostioles and gall-formation is also absent in both taxa.

Additional specimens examined. Panama: Panamá: Altos de Campana National Park, $50 \mathrm{~km}$ W of Panama City near the town of Capira, access gravel road leading to forest, $8^{\circ} 42^{\prime} \mathrm{N}, 79^{\circ} 57^{\prime} \mathrm{W}, 500-600 \mathrm{~m}$, submontane rainforest, on bark of exposed roadside trees, 14 iii 2009, R. Lücking s. n. (F).

\section{Astrothelium nicaraguense Lücking, M. P. Nelsen \& T. Orozco sp. nov.}

\author{
MycoBank No.: MB 817277
}

Differing from Astrothelium gigantosporum in the smaller ascospores.

Type: Nicaragua, Granada, Reserva Natural Volcán Mombacho, near Granada, $11^{\circ} 50$ 'N, $85^{\circ} 58^{\prime} \mathrm{W}, 1000 \mathrm{~m}$, montane rainforest, slightly disturbed forest along trail towards the crater, on fallen tree trunk, 22 April 2009, R. Lücking 28503 (HNMN-holotype; B-isotype).

\section{(Fig. 4E \& F)}

Thallus crustose, corticolous, continuous, $\leq 3 \mathrm{~cm}$ diam., uneven to bullate, olive-green; in section with thick, cartilaginous cortex and distinct, epiperidermal photobiont layer, and thick medulla.

Perithecia solitary or diffusely pseudostromatic, with separate, apical to slightly irregularly oriented ostioles, $0.9-1.2 \mathrm{~mm}$ diam., erumpent to prominent, $\leq 1 \mathrm{~mm}$ high, covered by an olive-green thallus layer except for the dark, grey-brown ostiolar area surrounded by a whitish rim; ostioles visible as black dots, $0.05-0.10 \mathrm{~mm}$ diam.; individual perithecia pyriform, $0.6-0.8 \mathrm{~mm}$ wide and $0.8-1.0 \mathrm{~mm}$ high. Excipulum in section 70-100 $\mu \mathrm{m}$ thick, carbonized. Hamathecium composed of densely anastomosing, $0.5 \mu \mathrm{m}$ thick, net-like paraphyses embedded in a gelatinous matrix, clear, IKI-; ostiolar channel clear. Ascospores 1 per ascus, oblongellipsoid, densely muriform, without median constriction, $160-180(-200) \times 40-50(-60) \mu \mathrm{m}$, hyaline, IKI-. 

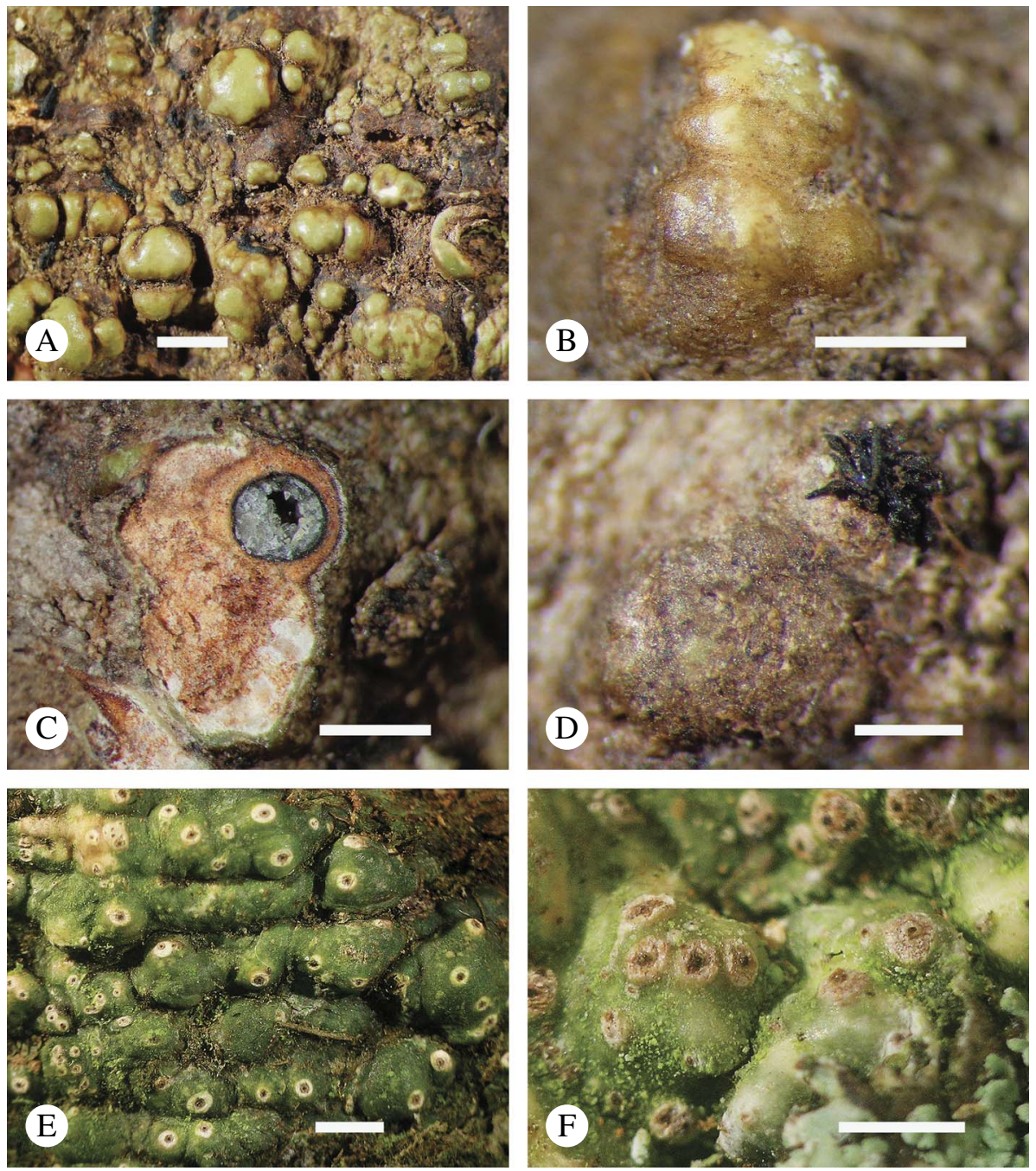

Fig. 4. A-D, Astrothelium megacrypticum (isotype): A-C, bullate thallus with immersed-erumpent ascomata visible by their ostioles; D, with immersed-erumpent ascomata visible by their extruded ascospores. $\mathrm{E} \& \mathrm{~F}$, A. nicaraguense (E, isotype; $\mathrm{F}$, Lücking 28546), thallus with erumpent to prominent, solitary to diffusely pseudostromatic ascomata. Scales: A-F $=1 \mathrm{~mm}$. In colour online.

Secondary chemistry. No substances detected.

Etymology. The name refers to the geographical situation of the type locality.

Notes. Astrothelium nicaraguense is most similar to $A$. gigantosporum in morphology, ascospore septation, and chemistry, but differs in the smaller ascospores without median constriction occurring 1 per ascus
(200-280 × 50-65 $\mu \mathrm{m}$, with median constriction and occurring 2 per ascus in the latter). Both species are related but phylogenetically distinct (Lücking et al. 2016).

Additional specimens examined. Nicaragua: Granada: Reserva Natural Volcán Mombacho, near Granada, $11^{\circ} 50^{\prime} \mathrm{N}, 85^{\circ} 58^{\prime} \mathrm{W}, 800 \mathrm{~m}$, montane rainforest, slightly disturbed forest along trail towards the crater, on tree trunk, 22 April 2009, R. Lücking 28546 (B), 28551 (F, HNMN). 
Astrothelium norisianum Lücking, M. P. Nelsen \& Aptroot sp. nov.

MycoBank No.: MB 817278

Differing from Astrothelium sepultum in the distinct, welldelimited pseudostromata.

Type: Panama, Panamá, Altos de Campana National Park, $50 \mathrm{~km} \mathrm{~W}$ of Panama City near the town of Capira, gravel road through forest, $8^{\circ} 42^{\prime} \mathrm{N}, 79^{\circ} 57^{\prime} \mathrm{W}$, 500-600 m, submontane rainforest, on bark of trees in shady understorey, 14 March 2009, R. Lücking 27178b (PMA-holotype; B, F-isotypes).

\section{(Fig. 5A)}

Thallus crustose, corticolous, continuous, $\leq 15 \mathrm{~cm}$ diam., uneven to coarsely bumpy with bumps $1-5 \mathrm{~mm}$ diam. (gall-forming), very pale olive-yellow; in section with thick, cartilaginous cortex and with photobiont layer and thick medulla immersed in the modified periderm.

Perithecia 5-10 aggregated and completely immersed in irregular to linear pseudostromata, with lateral, fused ostioles; pseudostromata 2-5 $\mathrm{mm}$ long and $1-3 \mathrm{~mm}$ wide, immersed but often developed on galls, often anastomosing, uneven, covered with a whitish layer, with one to several shared ostioles; ostioles papilliform, $0.05-0.10 \mathrm{~mm}$ diam., brownish; individual perithecia pyriform, arranged laterally with ostiolar channels oriented and fused irregularly, $0.3-0.5 \mathrm{~mm}$ wide and $\leq 1 \mathrm{~mm}$ long ('high'). Excipulum in section $20-30 \mu \mathrm{m}$ thick, dark brown to weakly carbonized; space between individual perithecia filled with amorphous, orange-brown tissue. Hamathecium composed of densely anastomosing, $0.5 \mu \mathrm{m}$ thick, net-like paraphyses embedded in a gelatinous matrix, clear, IKI-; upper part of hamathecium and ostiolar channel strongly inspersed. Ascospores 1-2 per ascus, oblong-ellipsoid, densely muriform with distinct median constriction and thick outer wall, $150-200 \times 50-60 \mu \mathrm{m}$, hyaline, IKI-.

Secondary chemistry. Thallus and pseudostromata with lichexanthone, UV+ yellow.

Etymology. This new species is dedicated to Prof. Dr Noris Salazar-Allen, renowned Panamanian botanist, for her numerous contributions to our knowledge of Panamanian cryptogams.

Notes. Astrothelium norisianum appears to be the only species with Cryptothelium morphology developing distinct, welldelimited pseudostromata. It is most similar to Astrothelium sepultum Mont., which has similarsized ascospores and also produces lichexanthone, but the perithecia are not arranged in distinct pseudostromata and the asci are consistently 2-spored; also, the ostiolar area is not inspersed. Astrothelium megalostomum (Vain.) Aptroot \& Lücking agrees in the (partially) inspersed hymenium but lacks distinct pseudostromata and only the perithecial warts are UV+ yellow.

Additional specimens examined. Panama: Panamá: Altos de Campana National Park, $50 \mathrm{~km}$ W of Panama City near the town of Capira, gravel road through forest, $8^{\circ} 42^{\prime} \mathrm{N}, 79^{\circ} 57^{\prime} \mathrm{W}, 500-600 \mathrm{~m}$, submontane rainforest, on bark of trees in shady understorey, 2009, R. Lücking 27178a (B, F, PMA).-Venezuela: Amazonas: Atabapo, surroundings of Culebra community, between Cerro Duida and Cerro Huachamacari, $03^{\circ} 40^{\prime} \mathrm{N}$, $65^{\circ} 45^{\prime} \mathrm{W}, 200-400 \mathrm{~m}$, Amazon forest interrupted by small savannas, 1982, M. Guariglia et al. 1485 (NY).Peru: Madre de Dios: Los Amigos Research and Training Center, Centro de Investigación y Capacitación Río Los Amigos (CICRA), $90 \mathrm{~km}$ W of Puerto Maldonado, $12^{\circ} 35^{\prime} \mathrm{S}, 70^{\circ} 06^{\prime} \mathrm{W}, 270 \mathrm{~m}$, tropical lowland rainforest, on bark of tree, 2008, M. P. Nelsen 4000d (F).

\section{Astrothelium obtectum Lücking, M. P. Nelsen \& Benatti sp. nov.}

MycoBank No.: MB 817279

Differing from Astrothelium nigrocacuminum in the smaller ascospores.

Type: Brazil, Minas Gerais, Serra do Caraça, Reserva Particular do Patrimônio Natural (RPPN) Santuário do Caraça, trail through forest to chapel, $20^{\circ} 06^{\prime} \mathrm{S}$, $43^{\circ} 29^{\prime} \mathrm{W}, 1300-1400 \mathrm{~m}$, Atlantic rainforest, relatively well-preserved gallery forest (mata de galeria or floresta ombrófila densa montana) along small river, 27 July 2010, R. Lücking 31242 (SP-holotype; B, F-isotypes).

\section{(Fig. 5B)}

Thallus crustose, corticolous, continuous, $\leq 10 \mathrm{~cm}$ diam., coarsely folded, olive-green; 

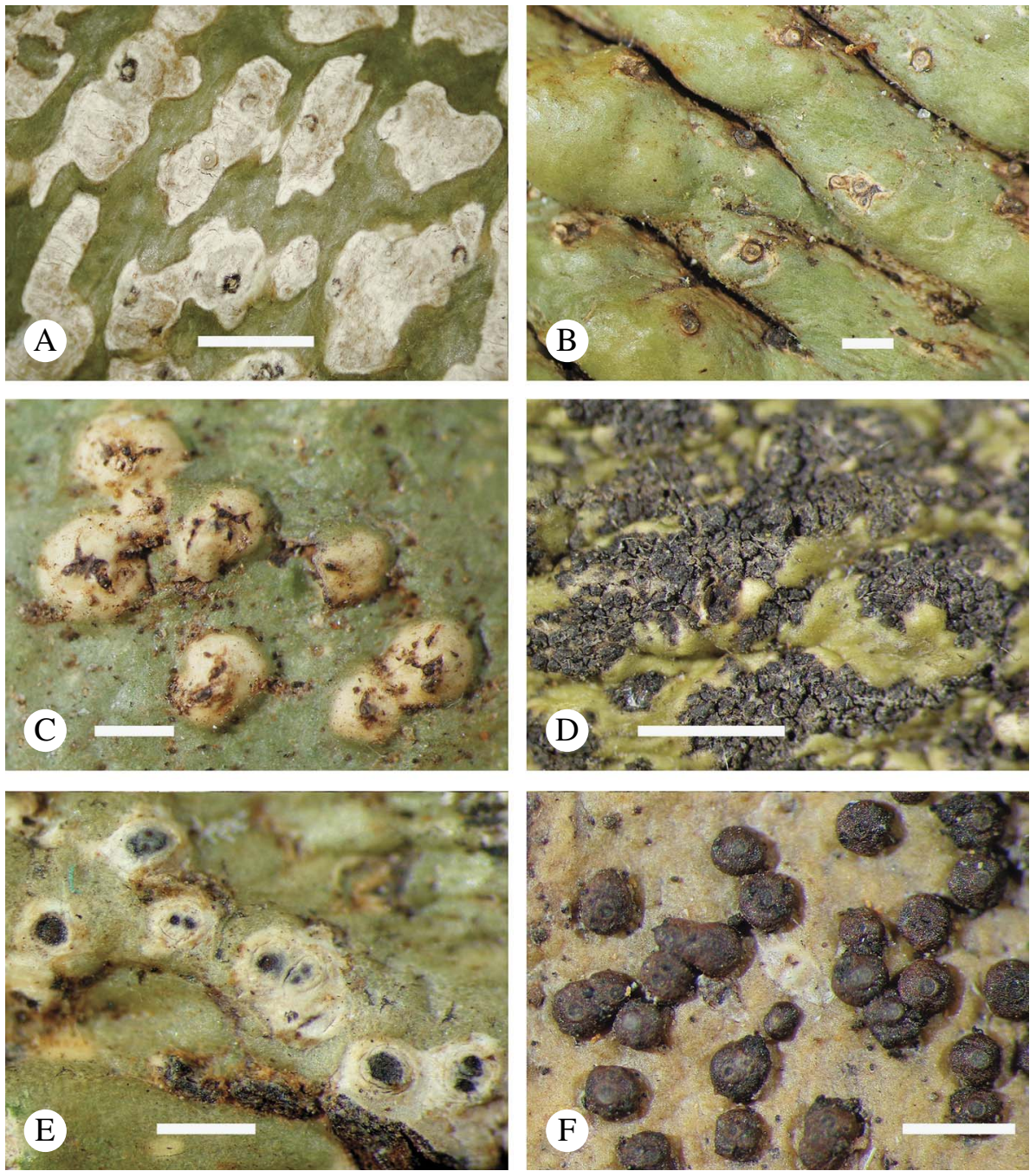

FIG. 5. A, Astrothelium norisianum (Guariglia et al. 1485), thallus with immersed-erumpent, sharply pseudostromatic ascomata; $\mathrm{B}, A$. obtectum (isotype), thallus with immersed ascomata; $\mathrm{C}, A$. sordithecium (isotype), thallus with erumpent to prominent ascomata covered by whitish layer; $\mathrm{D}, A$. subendochryseum (isotype), thallus with erumpent, confluent to pseudostromatic ascomata; E, A. subinterjectum (isotype), thallus with immersederumpent ascomata with whitish rim surrounding ostiolar area; F, Bathelium porinosporum (isotype), thallus with sessile, exposed ascomata. Scales: $\mathrm{A}-\mathrm{F}=1 \mathrm{~mm}$. In colour online.

in section with massive, cartilaginous cortex and distinct, epiperidermal photobiont layer, and indistinct medulla immersed in the periderm.

Perithecia 5-10 aggregated in rounded to irregular, diffuse pseudostromata, with fused, eccentric ostioles forming a common ostiole in the centre of the pseudotromata; pseudostromata $2-5 \mathrm{~mm}$ diam., erumpent, $\leq 1.5 \mathrm{~mm}$ thick, covered by olive-green thallus layer up to the shared ostiole; ostioles papilliform, $0.2-0.5 \mathrm{~mm}$ diam., brown with the surrounding area cream-coloured; individual perithecia pyriform, $0.4-0.6 \mathrm{~mm}$ wide and $\leq 1 \mathrm{~mm}$ high. Excipulum in section $50-80 \mu \mathrm{m}$ thick, carbonized, space between perithecia 
filled with amorphous, orange-brown tissue. Hamathecium composed of densely anastomosing, $0.5 \mu \mathrm{m}$ thick, net-like paraphyses embedded in a gelatinous matrix, clear, IKI-; ostiolar channel clear. Ascospores 8 per ascus, fusiform, 3-septate with distosepta and diamond-shaped lumina, 50-60 × 14-17 $\mathrm{m}$, hyaline, IKI-.

Secondary chemistry. Pseudostromata thinly covered with lichexanthone, UV+ orangeyellow.

Etymology. The epithet refers to the immersed perithecia covered by thallus tissue.

Notes. This new species has a typical Astrothelium morphology and is similar to taxa such as $A$. leucoconicum $\mathrm{Nyl}$. and A. nigrocacuminum Flakus et al. (Flakus et al. 2016). It differs from $A$. nigrocacuminum in the smaller ascospores and from $A$. leucoconicum in the clear hymenium and the slightly shorter and much narrower ascospores.

\section{Astrothelium sordithecium Lücking, M. P. Nelsen \& Marcelli sp. nov.}

$$
\text { MycoBank No.: MB } 817280
$$

Differing from Astrothelium leucothelium in the inspersed hymenium and the absence of lichexanthone from the thallus surface outside the pseudostromata.

Type: Brazil, Minas Gerais, Serra do Caraça, Reserva Particular do Patrimônio Natural (RPPN) Santuário do Caraça, Belchior trail, $20^{\circ} 06^{\prime} \mathrm{S}, 43^{\circ} 29^{\prime} \mathrm{W}$, $1300-1400 \mathrm{~m}$, Atlantic rainforest, disturbed gallery forest remnants (mata de galeria or floresta ombrófila densa montana) along small river leading to Cascatinha Waterfall, 27 July 2010, R. Lücking 31011 (SPholotype; F-isotype).

\section{(Fig. 5C)}

Thallus crustose, corticolous, continuous, $\leq 5 \mathrm{~cm}$ diam., smooth to uneven, olive-green to grey-green; in section with thick, cartilaginous cortex and distinct, epiperidermal photobiont layer, and distinct medulla partially immersed in the periderm and encrusted with numerous small, grey crystals.

Perithecia 4-8 aggregated in rounded to slightly irregular, distinct pseudostromata, with fused, eccentric ostioles forming 1-3 shared ostioles in the centre of the pseudotromata; pseudostromata 1-2 mm diam., prominent, $\leq 1 \mathrm{~mm}$ high, covered by a whitish thallus layer up to the shared ostioles; ostioles visible as small black dots, $0.08-0.10 \mathrm{~mm}$ diam., developed along narrowly triangular slits of the whitish layer that are visible as dark brown lines from above; individual perithecia pyriform, $0.4-0.5 \mathrm{~mm}$ wide and $\leq 0.6 \mathrm{~mm}$ high. Excipulum in section $30-50 \mu \mathrm{m}$ thick, carbonized, space between perithecia filled with amorphous, orange-brown tissue. Hamathecium composed of densely anastomosing, $0.5 \mu \mathrm{m}$ thick, net-like paraphyses embedded in a gelatinous matrix, densely inspersed with sordid yellowish brown oil droplets, IKI-; ostiolar channel inspersed. Ascospores 8 per ascus, fusiform, 3-septate with distosepta and diamond-shaped lumina, 30-40 × 10-12 $\mu \mathrm{m}$, hyaline, IKI-.

Secondary chemistry. Pseudostromata cortex with lichexanthone, UV+ yellow.

Etymology. The epithet refers to the yellowbrown inspersion of the hamathecium.

Notes. Astrothelium sordithecium is characterized by a dense, yellow-brown inspersion of the hamathecium somewhat resembling that of certain Pseudopyrenula species. It is probably related to $A$. variolosum (Ach.) Müll. Arg. and similar taxa. Astrothelium variolosum itself has smaller ascospores and the entire thallus is covered with lichexanthone. Astrothelium leucothelium Nyl. has similar-sized ascospores but a clear hamathecium and also the thallus contains lichexanthone.

\section{Astrothelium subendochryseum Lücking, M. P. Nelsen \& Marcelli sp. nov.} MycoBank No.: MB 817281

Differing from Astrothelium endochryseum in the absence of pigment in the pseudostromata and the lateral thallus cover of the pseudostromata.

Type: Brazil, Minas Gerais, Serra do Caraça, Reserva Particular do Patrimônio Natural (RPPN) Santuário do Caraça, Cascatinha Waterfall, $20^{\circ} 06^{\prime} \mathrm{S}, 43^{\circ} 29^{\prime} \mathrm{W}$, 
1300-1400 m, Atlantic rainforest, disturbed gallery forest remnants (mata de galeria or floresta ombrófila densa montana) near waterfall, 27 July 2010, R. Lücking 31088 (SP-holotype; B, F-isotypes).

(Fig. 5D)

Thallus crustose, corticolous, continuous, $\leq 7 \mathrm{~cm}$ diam., bullate, olive-green; in section with thick, cartilaginous cortex and distinct, epiperidermal photobiont layer, and thick medulla.

Perithecia 10-30 aggregated in irregular pseudostromata, with separate, apical ostioles; pseudostromata 1-3 mm diam., erumpent to prominent, $\leq 1 \mathrm{~mm}$ high, laterally covered by an olive-green thallus layer but individual perithecia exposed in upper part, dark grey-brown; ostioles visible as black dots, $0.05-0.10 \mathrm{~mm}$ diam.; individual perithecia pyriform, $0.25-0.35 \mathrm{~mm}$ wide and $0.3-0.5 \mathrm{~mm}$ high. Excipulum in section $30-60 \mu \mathrm{m}$ thick, carbonized. Hamathecium composed of densely anastomosing, $0.5 \mu \mathrm{m}$ thick, net-like paraphyses embedded in a gelatinous matrix, clear, IKI-; ostiolar channel clear. Ascospores 8 per ascus, fusiform, 3-septate with distosepta and diamond-shaped lumina, $22-25 \times 8-10 \mu \mathrm{m}$, hyaline, IKI-.

Secondary chemistry. No substances detected.

Etymology. The name refers to the close relationship with Astrothelium endochryseum.

Notes. This new species features the morphology of taxa previously placed in the genus Bathelium, but differs in the distinct lateral thallus cover of the pseudostromata and the absence of a medullary pigment in the pseudostromata. Anatomically it comes close to species of the Astrothelium nitidiusculum complex, but these species differ in the absence of Bathelium-like pseudostromata and are not closely related. The related $A$. endochryseum (Vain.) Aptroot \& Lücking differs chiefly in the orange medullary pigment and the larger ascospores.

Additional specimens examined. E1 Salvador: Suchitoto: Hacienda Colima, $13^{\circ} 56^{\prime} \mathrm{N}, 89^{\circ} 01^{\prime} \mathrm{W}, 400-450 \mathrm{~m}, 2009$, R. Lücking 28121 (F, ITIC).

\section{Astrothelium subinterjectum Lücking, M. P. Nelsen \& Jungbluth sp. nov.}

\author{
MycoBank No.: MB 817282
}

Differing from Astrothelium obtectum in the smaller pseudostromata and smaller ascospores, and from A. interjectum in the diffuse pseudostromata and smaller ascospores.

Type: Brazil, São Paulo, Pratânia, Fazenda Palmeira da Serra, $22^{\circ} 49^{\prime} \mathrm{S}, 48^{\circ} 45^{\prime} \mathrm{W}, 715 \mathrm{~m}$, gallery forest in Cerrado area, 15 July 2009, Nelsen B15 (SP-holotype; $\mathrm{B}, \mathrm{F}$-isotypes).

(Fig. 5E)

Thallus crustose, corticolous, continuous, $\leq 10 \mathrm{~cm}$ diam., uneven, olive-green; in section with cartilaginous cortex and epiperidermal photobiont layer, and indistinct medulla immersed in the periderm.

Perithecia 5-8 aggregated in rounded to irregular, diffuse pseudostromata, with fused, eccentric ostioles forming one to several, shared ostioles; pseudostromata $2-3 \mathrm{~mm}$ diam., erumpent, $\leq 1.2 \mathrm{~mm}$ thick, covered by olivegreen thallus layer up to the shared ostiole; ostioles papilliform, $0.2-0.4 \mathrm{~mm}$ diam., black with the surrounding area whitish; individual perithecia pyriform, $0.4-0.5 \mathrm{~mm}$ wide and $\leq 1 \mathrm{~mm}$ high. Excipulum in section $30-60 \mu \mathrm{m}$ thick, carbonized, space between perithecia filled with amorphous, orange-brown tissue. Hamathecium composed of densely anastomosing, $0.5 \mu \mathrm{m}$ thick, net-like paraphyses embedded in a gelatinous matrix, clear, IKI-; ostiolar channel clear. Ascospores 8 per ascus, fusiform, 3-septate with distosepta and diamond-shaped lumina, 20-25 × 7-9 $\mu \mathrm{m}$, hyaline, IKI-.

Secondary chemistry. Pseudostromata thinly covered with lichexanthone, UV+ (orange-) yellow.

Etymology. The epithet refers to the similarity with Astrothelium interjectum.

Notes. This new species is similar and closely related to Astrothelium obtectum described above, but is generally smaller in all dimensions and produces considerably smaller ascospores. Like Astrothelium obtectum, 
it is similar to $A$. crassum (Fée) Aptroot, A. interjectum R. C. Harris, and $A$. variolosum, but differs from those taxa in the broad, erumpent, diffuse pseudostromata, and also from $A$. crassum in the UV+ yellow pseudostromata, from $A$. interjectum in the smaller ascospores, and from $A$. variolosum in the UV- thallus.

\section{Bathelium porinosporum Lücking, M. P. Nelsen \& Gueidan sp. nov.}

MycoBank No.: MB 817283

Differing from other Bathelium species in the 3-septate, euseptate ascospores.

Type: Vietnam, Dong Nai, Western Highlands, Cát Tiên National Park, $6 \mathrm{~km}$ SW of the accommodation area, near a ranger house, 15 February 2012, C. Gueidan 3040 (BM-holotype, B, F, VNMN-isotypes).

\section{(Fig. 5F)}

Thallus crustose, corticolous, continuous, $\leq 10 \mathrm{~cm}$ diam., smooth to uneven, light olive; in section with thick, cartilaginous cortex and irregular photobiont layer immersed in the periderm.

Perithecia solitary, sessile with constricted base, with apical ostiole, lacking thalline cover, applanately subglobose, dark reddish brown, $0.4-0.5 \mathrm{~mm}$ wide and $0.25-0.30 \mathrm{~mm}$ high; ostiolar area flattened, appearing as a $0 \cdot 10$ $0.15 \mathrm{~mm}$ wide, grey-brown spot often separated by a thin slit. Excipulum in section $30-50 \mu \mathrm{m}$ thick, carbonized, laterally covered by amorphous, orange-brown tissue and what appears to be a carbonized cortex. Hamathecium composed of densely anastomosing, $0.5 \mu \mathrm{m}$ thick, net-like paraphyses embedded in a gelatinous matrix, clear, IKI-; ostiolar channel clear. Ascospores 8 per ascus, fusiform, 3-5-septate (eusepta only), 20-30 $\times$ 6-7 $\mu \mathrm{m}$, hyaline, IKI-.

Secondary chemistry. Perithecial wall with a thinly dispersed, reddish brown pigment that bleeds first deep yellow, then deep orange to cinnabar red.

Etymology. The epithet refers to the porinoid ascospores.
Notes. Bathelium porinosporum is characterized by the typical Bathelium-like, sessile, dark brown perithecia, in combination with transversely septate ascospores. It is the only species thus far recognized in the genus with transversely septate ascospores. The ascospores are notably euseptate (thin walls and septa) and if observed without context closely resemble those of the unrelated genus Porina.

In addition to the mtSSU and nuLSU sequence data published elsewhere for this taxon (Lücking et al. 2016), the following ITS barcode locus data were also generated: Gueidan 3040 (the holotype; KU504486), Gueidan 3018 (KU504485), Gueidan 3041 (KU504487), Gueidan 3053 (KU504488), Gueidan 3055 (KU504489).

Additional specimens examined. Vietnam: Western Highlands: Dong Nai Province, Cát Tiên National Park, $6 \mathrm{~km} \mathrm{SW}$ of the accommodation area, near a ranger house, 2012, Gueidan 3041 (BM, F, VNMN); ibid., $10 \mathrm{~km} \mathrm{SW}$ of the accommodation area, in a tree plantation near a gate leading to the minority village, 2012, Gueidan 3053 (BM, F, VNMN), Gueidan 3055, (BM, VNMN); ibid., on Dipterocarpus planted along the road heading south of the accommodation area, 2012, Gueidan 3018 (BM, F, VNMN).

\section{Nigrovothelium bullatum Lücking, Upreti \& Lumbsch sp. nov.}

\section{MycoBank No.: MB 817285}

Differing from Nigrovothelium tropicum in the bullate thallus.

Type: India, Tamil Nadu, Eastern Ghat, Chennai, Mamallapuram, $40 \mathrm{~m}$, disturbed dry evergreen forest with cashew nut trees, on cashew nut tree, 9 January 2008, H. T. Lumbsch, D. K. Upreti, P. K. Divakar E F. Tandon 19701-b (LWG-holotype; $\mathrm{B}, \mathrm{F}$-isotypes).

\section{(Fig. 6A)}

Thallus crustose, corticolous, continuous, $\leq 10 \mathrm{~cm}$ diam., strongly verrucose-bullate, olivegreen to olive-brown; in section with thick, cartilaginous cortex and distinct, epiperidermal photobiont layer, and thick medulla.

Perithecia solitary but dense and often confluent, with separate, apical ostioles, $0.2-0.3 \mathrm{~mm}$ diam., sessile, $\leq 0.25 \mathrm{~mm}$ high, 

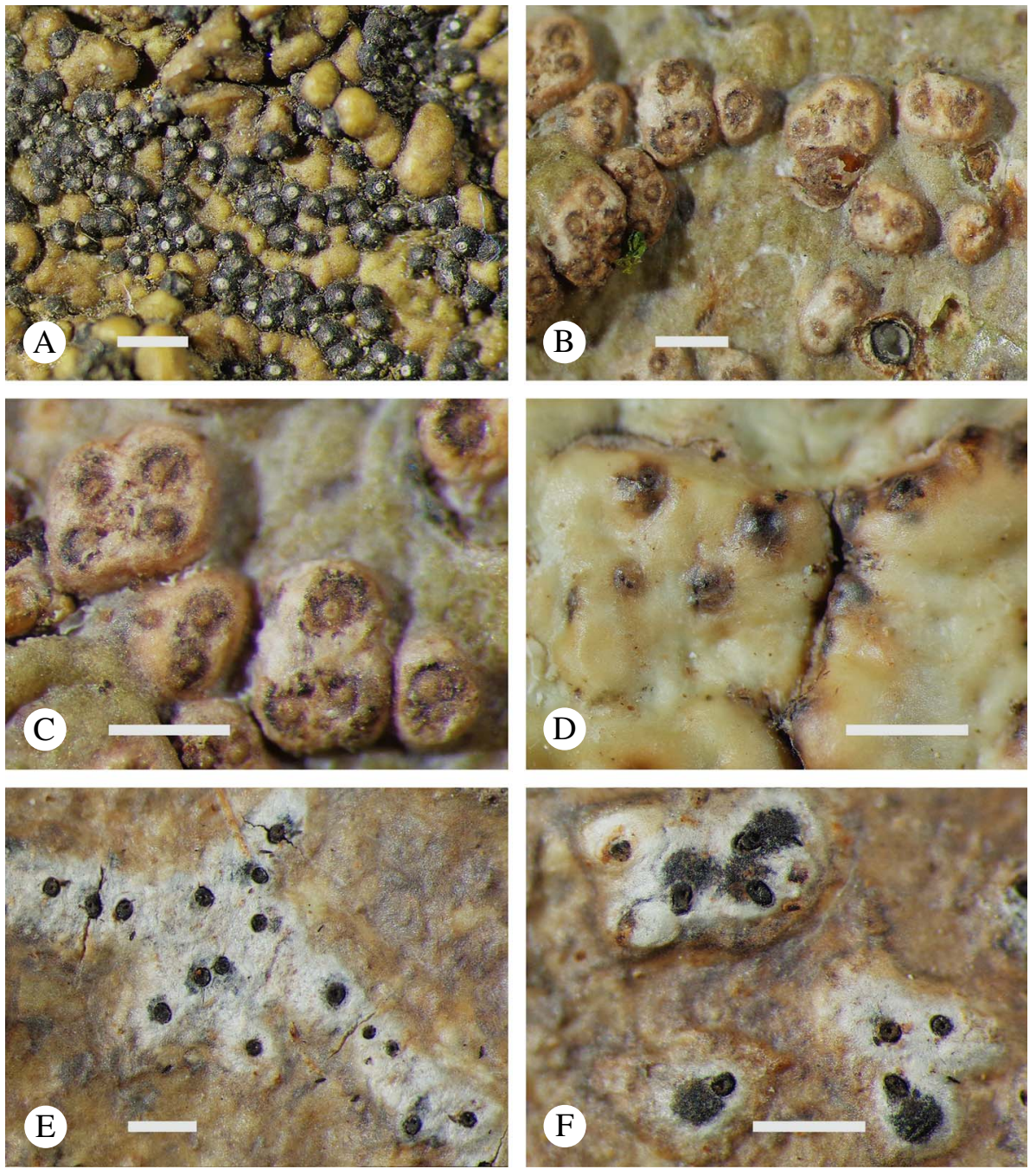

FIG. 6. A, Nigrovothelium bullatum (isotype), bullate thallus with exposed ascomata; B \& C, Trypethelium tolimense (isotype), thallus with pseudostromatic ascomata; D, Viridothelium vonkonratii (isotype), thallus with immersederumpent ascomata; E \& F, V. tricolor (isotype), thallus with immersed-erumpent, confluent to pseudostromatic ascomata with whitish cover and black ostiole. Scales: A-F $=1 \mathrm{~mm}$. In colour online.

exposed, black, ostiolar area grey; ostioles visible as tiny black dots. Excipulum in section $50-100 \mu \mathrm{m}$ thick, carbonized. Hamathecium composed of densely anastomosing, $0.5 \mu \mathrm{m}$ thick, net-like paraphyses embedded in a gelatinous matrix, clear, IKI-; ostiolar channel clear. Ascospores 8 per ascus, fusiform, 3-septate with distosepta and diamond-shaped lumina, $20-25 \times 8-10 \mu \mathrm{m}$, hyaline, IKI-.
Secondary chemistry. No substances detected.

Etymology. The name refers to the strongly bullate thallus.

Notes. This new species is closely related to the taxon previously known as Trypethelium tropicum (Ach.) Müll. Arg. and now placed in the genus Nigrovothelium (Lücking et al. 2016). Both species agree in morphological 
and anatomical details of the perithecia, but while N. tropicum (Ach.) Lücking et al. has a smooth to uneven thallus, that of $N$. bullatum is strongly verrucose bullate. The recognition of the latter as a distinct species is supported by molecular data (Lücking et al. 2016).

\section{Trypethelium tolimense Lücking, Moncada \& M. Gut. sp. nov.}

\section{MycoBank No.: MB 817286}

Differing from Trypethelium xanthoplatystomum in the absence of a yellow-orange pigment on the pseudostromata and the $\mathrm{K}+$ yellow (not $\mathrm{K}+$ red) medullary pigment.

Type: Colombia, Tolima, Purificacion, Vereda El Tambo, Finca El Santuario; $3^{\circ} 41^{\prime} \mathrm{S}, 74^{\circ} 54^{\prime} \mathrm{W}, 300-350 \mathrm{~m}$, disturbed forest remnants on finca, 10 August 2010, $R$. Lücking \& B. Moncada 32593 (UDBCholotype; B-isotype).

\section{(Fig. 6B \& C)}

Thallus crustose, corticolous, continuous, $\leq 5 \mathrm{~cm}$ diam., smooth to uneven, light olive; in section with thick, cartilaginous cortex, thick, epiperidermal photobiont layer, and thin medulla immersed in the periderm.

Perithecia (1-)3-10 aggregated in rounded to irregular pseudostromata, with separate, apical ostioles; pseudostromata (0.6-)1.0$3.0 \mathrm{~mm}$ diam., prominent, $\leq 0.5 \mathrm{~mm}$ high, covered by a brownish white thallus layer contrasting with the surrounding thallus; internally between the perithecia filled with light yellow, $\mathrm{K}+$ yellow pigment granules, in section bleeding yellow; ostioles papilliform, $0.05-0.10 \mathrm{~mm}$ wide, whitish translucent, surrounded by a dark brown rim; individual perithecia subglobose, $0.4-0.5 \mathrm{~mm}$ wide and $0.3-0.4 \mathrm{~mm}$ high. Excipulum in section $20-50 \mu \mathrm{m}$ thick, carbonized except near the ostiole, laterally covered by yellow pigment granules. Hamathecium composed of densely anastomosing, $0.5 \mu \mathrm{m}$ thick, net-like paraphyses embedded in a gelatinous matrix, clear, IKI-; ostiolar channel clear. Ascospores 8 per ascus, narrowly fusiform, 11-15-septate with eusepta and angular lumina, 70-80 × 10$12 \mu \mathrm{m}$, hyaline, IKI-.

Secondary chemistry. Thallus and pseudostromata with lichexanthone, UV+ yellow; medulla of pseudostromata with pale yellow pigment, bleeding yellow.

Etymology. Referring to the geographical location of the type locality.

Notes. This new species features a typical Trypethelium morphology and ascospores, but is set apart from other species of the genus by the presence of lichexanthone on the thallus and pseudostromata, in combination with the pale yellow, $\mathrm{K}+$ yellow medullary pigment of the pseudostromata. Three other species in the genus contain lichexanthone: Trypethelium regnellii Malme and T. luteolucidum Aptroot et al. have an inspersed hamathecium and larger ascospores, and lack a medullary pigment, whereas $T$. xanthoplatystomum Flakus \& Aptroot has pseudostromata covered with a yellow-orange pigment and the medullary pigment is orange and reacts $\mathrm{K}+$ red. Also, in all other species of the genus with a medullary pigment, the pigment reacts $\mathrm{K}+$ red or purple.

\section{Viridothelium tricolor Lücking,} M. P. Nelsen \& N. Salazar sp. nov.

\author{
MycoBank No.: MB 817287
}

Characterized by black perithecia with a lateral ostiole immersed in white pseudostromata strongly contrasting with the surrounding brown thallus, in combination with 2-spored asci and large, muriform ascospores.

Type: Panama, Panamá, Altos de Campana National Park, $50 \mathrm{~km} \mathrm{~W}$ of Panama City near the town of Capira, access gravel road leading to forest, $8^{\circ} 42^{\prime} \mathrm{N}, 79^{\circ} 57^{\prime} \mathrm{W}$, 500-600 m, submontane rainforest, on bark of exposed roadside trees, 15 March 2011, M. P. Nelsen s.n. (PMA-holotype; B, F-isotypes).

(Fig. 6E \& F)

Thallus crustose, corticolous, continuous, $\leq 7 \mathrm{~cm}$ diam., smooth to uneven, reddish to yellowish brown; in section thinly corticate, with photobiont layer immersed in the uppermost periderm layers.

Perithecia solitary or more commonly (2-) $3-10(-20)$ aggregated in irregular to elongate pseudostromata with separate, eccentric to lateral, rarely apical ostioles; pseudostromata 
1-10 $\mathrm{mm}$ long and $1-3 \mathrm{~mm}$ wide, immersed to erumpent, $\leq 0.8 \mathrm{~mm}$ high, white and strongly contrasting with the surrounding thallus, individual perithecia usually completely immersed but sometimes visible as grey-black bumps; ostioles distinct, not fused, forming blackish spots, $0 \cdot 15-0.25 \mathrm{~mm}$ diam., strongly contrasting with the white pseudostromata and the brown thallus; individual perithecia pyriform with short ostiolar channel, $0.5-0.7 \mathrm{~mm}$ wide and $\leq 0.7 \mathrm{~mm}$ high. Excipulum in section $50-200 \mu \mathrm{m}$ thick, strongly carbonized; narrow space between individual perithecia filled with amorphous, orange-brown tissue. Hamathecium composed of densely anastomosing, $0.5 \mu \mathrm{m}$ thick, net-like paraphyses embedded in a gelatinous matrix, clear, IKI-; ostiolar channel clear. Ascospores 2 per ascus, oblong-ellipsoid, richly muriform with more or less thin eusepta, 120-150 × 30-40 $\mu \mathrm{m}$, hyaline, IKI-.

Secondary chemistry. No substances detected.

Etymology. The name refers to the conspicuous colour contrast between the thallus and the pseudostromata.

Notes. This new species was at first mistaken for Campylothelium puiggarii, based on depauperate material from Venezuela. However, the material from Panama underlines the considerable differences, in particular the morphology with the black perithecia immersed in white pseudostromata that strongly contrast with the surrounding thallus. This species shares most key characters with the unrelated Astrothelium campylocartilagineum Aptroot and A. andamanicum (Makhija \& Patw.) Aptroot, neither of which have distinct pseudostromata. In spite of these similarities, it clusters within the newly established genus Viridothelium (Lücking et al. 2016).

Additional specimens examined. Panama: Panamá: Altos de Campana National Park, $50 \mathrm{~km}$ W of Panama City near the town of Capira, access gravel road leading to forest, $8^{\circ} 42^{\prime} \mathrm{N}, 79^{\circ} 57^{\prime} \mathrm{W}, 500-600 \mathrm{~m}$, submontane rainforest, on bark of exposed roadside trees, 2009, R. Lücking 27014p (F, PMA), 27057 (B), 27085 (F, PMA).-Venezuela: Aragua: Henri Pittier National Park, Dr Alberto Fernández Yépez Biological Station, $\mathrm{km} 12$ on road from Maracay to Ocumare, Andrew Field Trail, $10^{\circ} 21^{\prime} \mathrm{N}, 67^{\circ} 40^{\prime} \mathrm{W}, 1100-1200 \mathrm{~m}$, tropical cloud forest, 2010, R. Lücking 32241 (B, VEN).

\section{Viridothelium vonkonratii Lücking, Naksuwankul \& Lumbsch sp. nov.}

\section{MycoBank No.: MB 817288}

Differing from Viridothelium virens in the larger ascospores. Type: Fiji, Kadavu Island, $19^{\circ} 02^{\prime} \mathrm{S}, 178^{\circ} 11^{\prime} \mathrm{E}$, on bark, 2011, H. T. Lumbsch E K. B. Naksuwankul 20551a (SUVA - holotype; B, F, MSUT-isotypes).

\section{(Fig. 6D)}

Thallus crustose, corticolous, continuous, $\leq 10 \mathrm{~cm}$ diam., uneven to bumpy (gallforming), very pale olive-yellow; in section corticate, with photobiont layer deeply immersed in the modified periderm.

Perithecia solitary or becoming crowded, with separate, lateral ostiole, almost completely immersed in the thallus or upper portion erumpent and appearing dark greyish, $0.5-0.7 \mathrm{~mm}$ diam. and $\leq 1 \mathrm{~mm}$ high. Excipulum in section $20-30 \mu \mathrm{m}$ thick, weakly carbonized, laterally covered with a thin layer of amorphous, orangebrown tissue. Hamathecium composed of densely anastomosing, $0.5 \mu \mathrm{m}$ thick, net-like paraphyses embedded in a gelatinous matrix, clear, IKI-; ostiolar channel clear. Ascospores 8 per ascus, oblong-fusiform, 15-21-septate, with distinct distosepta and diamond-shaped lumina, $90-100 \times 22-26 \mu \mathrm{m}$, hyaline, IKI-.

Secondary chemistry. No substances detected.

Etymology. Named after our esteemed colleague and renowned bryologist, Matt von Konrat, who organized the field trip.

Notes. The genus Viridothelium is in most aspects similar to Astrothelium. The two genera cannot be readily separated based on morphology, except for the thin-walled ascospores in Viridothelium (similar to those of Trypethelium); phylogenetically, they are only distantly related. Apparently, both genera can include species with transversely 
septate and others with muriform ascospores. This is another species in Viridothelium known with transversely septate ascospores, similar to those of $V$. virens (Tuck. ex Michener) Lücking et al.. Viridothelium vonkonratii differs from the latter in ascospore size and septation, as well as the solitary to crowded, but not pseudostromatic ascomata.

We are grateful to the National Science Foundation for funding aspects of this work through the grant NSFDEB 0715660 "Neotropical Epiphytic Microlichens An Innovative Inventory of a Highly Diverse yet Little Known Group of Symbiotic Organisms" to The Field Museum (PI Robert Lücking). The Caterpillar ${ }^{\circledR}$ Company provided additional funds to study lichens from Panama. MN was further supported through a grant from the Committee on Evolutionary Biology (University of Chicago), a Graduate Student Research Grant from The American Society of Plant Taxonomists, and a Brown Family Fellowship through the Field Museum, as well as a William Harper Rainey Fellowship through the University of Chicago. Field support in Panama was provided by the University of Panama (Department of Botany) in the development of two lichen seminars $(2009,2011)$ during which the lichens were collected. Thanks also to Park authorities and rangers of Parque Nacional Altos de Campana during the field trips and to the Ministry of the Environment (formerly A.N.A.M.) for collection and export permits. In Colombia, logistical support was provided by the Universidad Distrital Francisco José de Caldas and the Cardenas Herrera family for access to their Finca El Santuario. For field support in Brazil, we thank the Universidade Estadual Paulista, campus Botucatu, and the administration of the Santuário do Caraça, as well as the owners of Fazenda Palmeira da Serra in São Paulo State. Work on Fiji was supported by the National Geographic Committee for Research and Exploration, Grant No. 8247-07. For field work in New Caledonia, we thank the Thai Research Fund and Mahasarakham University for providing financial assistance (K. Papong RSA 5580045), the National Science Foundation (Awards No. DEB-1025861 and DEB-1145898), the Mohamed bin Zayed Species Conservation Fund (Award No. 11253111), and the Negaunee Foundation. We also thank 'Direction du développement économique et de l'environnement de la Province Nord', and 'Direction de l'environnement de la Province Sud' for plant permits to both provinces. KN also thanks Mahasarakham University, Thailand. The Universidad Distrital Francisco José de Caldas in Bogotá, Colombia, is thanked for providing support to $\mathrm{BM}$ as part of the program 'Movilidad Académica' for professors.

\section{REFERENCES}

Aptroot, A. (1991) A monograph of the Pyrenulaceae (excluding Anthracothecium and Pyrenula) and the Requienellaceae, with notes on the Pleomassariaceae, the Trypetheliaceae and Mycomicrothelia (lichenized and non-lichenized Ascomycetes). Bibliotheca Lichenologica 44: 1-178.

Aptroot, A. (2009a) Trypetheliaceae. Flora of Australia 57: 535-552.

Aptroot, A. (2009b) Diversity and endemism in the pyrenocarpous lichen families Pyrenulaceae and Trypetheliaceae in the Malesian flora region. Blumea 54: 145-147.

Aptroot, A. \& Cáceres, M. E. S. (2016) New Trypetheliaceae from the Amazon basin in Rondônia (Brazil), the centre of diversity of the genus Astrothelium. Lichenologist 48: 693-712.

Aptroot, A. \& Lücking, R. (2016) A revisionary synopsis of the Trypetheliaceae (Ascomycota: Trypetheliales). Lichenologist 48: 763-982.

Aptroot, A., Lücking, R., Sipman, H. J. M., Umaña, L. \& Chaves, J. L. (2008) Pyrenocarpous lichens with bitunicate asci: a first assessment of the lichen biodiversity inventory of Costa Rica. Bibliotheca Lichenologica 97: 1-162.

Aptroot, A., Menezes, A. A., Lima, E. L., Xavier-Leite, A. B. \& Cáceres, M. E. S. (2013) New species of Polymeridium from Brazil expand the range of known morphological variation within the genus. Lichenologist 45: 545-552.

Córdova-Chávez, O., Aptroot, A., Castillo-Camposa, G., Cáceres, M. E. S. \& Pérez-Pérez, R. E. (2014) Three new lichen species from cloud forest in Veracruz, Mexico. Cryptogamie, Mycologie 35: 157-162.

Flakus, A., Kukwa, M. \& Aptroot, A. (2016) Trypetheliaceae of Bolivia: an updated checklist with descriptions of twenty-four new species. Lichenologist 48: 661-692.

Komposch, H. \& Hafellner, J. (1999) List of lichenized fungi so far observed in the tropical lowland rain forest plot Surumoni (Venezuela, Estado Amazonas). Fritschiana 19: 1-10.

Komposch, H. \& Hafellner, J. (2000) Diversity and vertical distribution of lichens in a Venezuelan tropical lowland rain forest. Selbyana 21: 11-24.

Komposch, H. \& Hafellner, J. (2002) Life form diversity of lichenized fungi in an Amazon lowland rain forest. Bibliotheca Lichenologica 82: 311-326.

Komposch, H. \& Hafellner, J. (2003) Species composition of lichen dominated corticolous communities: a lowland rain forest canopy compared to an adjacent shrubland in Venezuela. Bibliotheca Lichenologica 86: 351-367.

Komposch, H., Aptroot, A. \& Hafellner, J. (2002) New species of lichenized and non-lichenized ascomycetes from canopy in southern Venezuela. Lichenologist 34: 223-235.

Lima, E. L., Maia, L. C., Aptroot, A. \& Cáceres, M. E. S. (2013) New lichen species from Vale do Catimbau, Pernambuco, Brazil. Bryologist 116: 327-329.

Lücking, R., Nelsen, M. P., Aptroot, A., Barillas de Klee, R., Bawingan, P. A., Benatti, M. N., Binh, N. Q., Bungartz, F., Cáceres, M. E. S., Canêz, L. S., et al. (2016) A phylogenetic framework for reassessing generic concepts and species delimitation in the lichenized family Trypetheliaceae (Ascomycota: Dothideomycetes). Lichenologist 48: 739-762. 
Nelsen, M. P., Lücking, R., Grube, M., Mbatchou, J. S., Muggia, L., Rivas Plata, E. \& Lumbsch, H. T. (2009) Unravelling the phylogenetic relationships of lichenised fungi in Dothideomyceta. Studies in Mycology 64: 135-144.

Nelsen, M. P., Lücking, R., Mbatchou, J. S., Andrew, C. J., Spielmann, A. A. \& Lumbsch, H. T. (2011) New insights into relationships of lichen-forming Dothideomycetes. Fungal Diversity 51: 155-162.

Nelsen, M. P., Lücking, R., Aptroot, A., Andrew, C. J., Cáceres, M. E. S., Rivas Plata, E., Gueidan, C., da Silva Canêz, L., Knight, A., Ludwig, L. R., et al. (2014) Elucidating phylogenetic relationships and genus-level classification within the fungal family Trypetheliaceae (Ascomycota: Dothideomycetes). Taxon 63: 974-992.

Orange, A., James, P. W. \& White, F. J. (2010) Microchemical Methods for the Identification of Lichens. London: British Lichen Society.

Weerakoon, G. \& Aptroot, A. (2014) Over 200 new lichen records from Sri Lanka, with three new species to science. Cryptogamie, Mycologie 35: 51-62. 